\title{
Comparison of Stenocarpella maydis Isolates for Isozyme and Cultural Characteristics
}

A. E. Dorrance, Department of Plant Pathology, The Ohio State University, Wooster 44691; O. K. Miller, Department of Biology, and H. L. Warren, Department of Plant Pathology, Physiology and Weed Science, Virginia Polytechnic Institute and State University, Blacksburg 24061-0331

\begin{abstract}
Dorrance, A. E., Miller, O. K., and Warren, H. L. 1999. Comparison of Stenocarpella maydis isolates for isozyme and cultural characteristics. Plant Dis. 83:675-680.

Isolates of Stenocarpella maydis from seed companies and plant disease clinics in the United States and the Republic of South Africa were assayed for isozyme polymorphisms and cultural variability. A low level of isozyme polymorphisms was detected in this collection of isolates. Isozyme polymorphisms were detected for $\alpha$-esterase, hexose kinase, and malate dehydrogenase of the enzymes assayed. Fungi often have limited variability among isozyme profiles, and this is especially true for fungi that have host specialization such as biotrophs or fungi with formae speciales designations. Optimum growth temperature, colony color, and pycnidiospore production were also measured. All isolates had an optimum temperature of 28 to $31^{\circ} \mathrm{C}$ for colony growth on acidified potato dextrose agar. Colony color and pycnidiospore production were variable over the course of several experiments, indicating that these phenotypes are poor genetic markers.
\end{abstract}

Additional keywords: Diplodia ear rot, Diplodia stalk rot, maize

Understanding the genetic structure of fungal plant pathogen populations can aid disease management decisions (42). Little is known about the population biology of Stenocarpella maydis (Berk.) Sutton (=Diplodia maydis (Berk.) Sacc.), the cause of Diplodia ear rot and Diplodia stalk rot of maize (Zea mays L.). This fungus was the predominant ear rot pathogen during the early part of this century. However, Hooker and White (16) reported a decline in occurrence of Diplodia ear rot in the 1970s. Latterell and Rossi (23) reported an increase in occurrence of this disease during the early 1980s, and from 1992 to 1996, significant losses were reported from Diplodia ear rot in the United States (M. A. Hanson, 1992, VPI \& SU Department of Plant Pathology, Physiology and Weed Science, Plant Clinic Record 2102; P. Vincelli, 1992 and 1994, personal communication; 31$)$. The increase in incidence of Diplodia ear rot may have resulted from a decline in host resistance, utilization of cultural practices such as no-till that result in an increase in inoculum (23), or changes in the virulence or aggressiveness of the fungus.

There are several reports of variability in $S$. maydis. Hoppe (17) discovered aver-

\section{Corresponding author: A. E. Dorrance}

E-mail: dorrance.1@osu.edu

Accepted for publication 19 March 1999.

Publication no. D-1999-0503-02R

(C) 1999 The American Phytopathological Society sions, an inhibition of growth at the edge of cultures, among isolates on culture media and in host tissue. Young et al. (45) examined isolates from several states on a set of $F_{1}$ entries and found differences in pathogenicity for maize stalk rot and mycelial growth temperature requirements. Kappelman et al. (19) reported significant differences among isolates for stalk rot severity. Ullstrup (39) found no differences in incidence of ear rot caused by five isolates collected from separate maize production areas. Maxwell and Thompson (26) reported significant differences in stalk rot severity among combinations of maize lines and testers challenged with "highly or weakly virulent" isolates. Several researchers have adapted their studies to account for some of these differences by using several isolates with varying degrees of "aggressiveness" (measured by the relative amounts of stalk rot or ear rot) or production of high numbers of pycnidiospores $(6,25,41)$.

Genetic variation among isolates of a fungus has been examined through a variety of techniques (20,27-29). Isozyme analysis has proven to be a useful tool at the species level for numerous plant pathogenic fungi (2). Because variation in $S$. maydis has been reported previously, we chose to analyze isozyme polymorphisms within a set of isolates from a broad geographic region of the United States and from the Republic of South Africa. Diplodia ear rot and Diplodia stalk rot are yieldlimiting diseases of maize in the Republic of South Africa $(1,6,11)$.
The purpose of this study was to characterize a set of $S$. maydis isolates for isozyme phenotypes and cultural characteristics. Isozyme analyses were completed on intracellular enzymes. Production of cellulolytic and pectolytic enzymes of this fungus have been reported previously (1); therefore, the isozyme profile of pectolytic enzymes was also investigated. Abstracts of this research were presented earlier $(8,9)$.

\section{MATERIALS AND METHODS}

Fungal strains. Forty-six isolates of $S$. maydis were obtained from maize seed companies and plant disease clinics in the United States and the Republic of South Africa (Table 1). Kernels from S. maydiscolonized maize ears were placed in $10 \%$ sodium hypochlorite solution for $1 \mathrm{~min}$, rinsed twice in sterile distilled water, and placed on acidified potato dextrose agar (APDA) to allow for development of pycnidia. Single pycnidiospores were placed on APDA with 12 autoclaved maize kernels. After 2 to 3 weeks, colonized kernels were shaken in tubes of sterile distilled water, and the resulting spore suspension was brought to $10 \%$ glycerol (vol/vol) solution and stored at $-80^{\circ} \mathrm{C}$ until used. Colonized kernels were also stored in sterile glass tubes at $4^{\circ} \mathrm{C}$. A few isolates were grown on sterile washed toothpicks (21 days), lyophilized, and stored at room temperature (44). Diplodia nataliensis Pole-Evans was used as an outgroup for isozyme analysis.

Sample preparation. To obtain mycelial extracts for intracellular enzymes, two 5-mm plugs of mycelia from a 6- to 7-dayold culture were transferred to $75 \mathrm{ml}$ of potato dextrose broth in 125-ml Erlenmeyer flasks and incubated without agitation at $25^{\circ} \mathrm{C}$ for 5 to 6 days under $24-\mathrm{h}$ light $(24 \mathrm{~W}$ cool white, General Electric, Cleveland, OH). Mycelial mats were collected onto filter paper with vacuum filtration, rinsed with sterile distilled water, frozen with liquid nitrogen, and ground to a fine powder with a mortar and pestle. Extraction buffer (approximately $2 \mathrm{ml}$ of $0.05 \mathrm{M}$ Tris, $\mathrm{pH} 7.5$, 5\% glycerol) was added to the powdered mycelia and mixed by vortexing, and samples were centrifuged twice (Compac10F/Compac 10V centrifuge, Fisher Scientific, Pittsburgh, PA) at $5,500 \times g$ at $4^{\circ} \mathrm{C}$ for $10 \mathrm{~min}$. The supernatant was frozen at $-80^{\circ} \mathrm{C}$ until used. 
Electrophoresis. Protein extracts were subjected to vertical polyacrylamide gel electrophoresis. Native polyacrylamide electrophoresis was conducted using a BioRad Mini-PROTEAN II Apparatus (BioRad Laboratories, Hercules, CA). Extracts were run on $7.5 \%$ acylamide, except for detection of malate dehydrogenase and $\alpha$-esterase, which were separated on $10.0 \%$ acrylamide. The gel buffer was $0.375 \mathrm{M}$ Tris- $\mathrm{HCl}$ ( $\mathrm{pH} 8.8$ ), running buffer

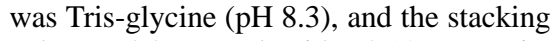
gel was $4.0 \%$ acrylamide, $0.125 \mathrm{M}$ Tris$\mathrm{HCl}$ (pH 6.8). Approximately 10 to $15 \mu \mathrm{l}$ of protein extract was placed in wells with sample buffer (0.5 M Tris-HCl, pH 6.8, $1 \%$ glycerol, and $0.05 \%$ bromophenol blue). Electrophoresis was conducted for $45 \mathrm{~min}$ at $200 \mathrm{~V}$ or until the dye front reached the bottom of the gel. One standard isolate was used in each electrophoretic assay. Ten isozymes were analyzed for polymorphisms following published procedures (Table 2; 4,29,36,40,43). Electrophoretic mobility of the various enzymes was represented as $R_{f}$ values, described by Bosland and Williams (3).

Forty $S$. maydis isolates were also examined for pectolytic enzyme production. Isolates of $S$. maydis were grown on $25 \mathrm{ml}$ of liquid medium, as previously reported by Morant et al. (30). Carbon source substitution was made with $5 \%$ acid washed polygalacturonic acid (PGA). Two 5-mm colonized plugs of mycelia from 5- to 6day-old cultures were placed in 100-ml bottles. Plastic recycling bins (approximately $30 \mathrm{~cm}$ long by $45 \mathrm{~cm}$ wide by 30 $\mathrm{cm}$ high) with a clear plastic cover in which lights had been added were used to incubate bottles under 12-h light $(23 \mathrm{~mm}$ below light source, GE Rapid Start
FC8T9-WW warm white, General Electric) at room temperature $\left(25\right.$ to $\left.27^{\circ} \mathrm{C}\right)$ Following a 10- to 14-day incubation, $2 \mathrm{ml}$ of culture liquid was placed in a $10 \mathrm{MW}$ concentrator (Centricon, Amicon, Inc., Beverly, MA) and centrifuged at 4,000 $\times g$ for $90 \mathrm{~min}$. The concentrated protein was then used immediately for isoelectric focusing-polyacrylamide gel electrophoresis (IEF-PAGE).

Ultrathin IEF-PAGE gels were cast on acrylamide support film (FMC, Rockland, ME). The gels were composed of $16.6 \%$ acrylamide and $5.0 \%$ glycerol, and $2 \%$ ampholytes were $\mathrm{pH} 3$ to 10 (Sigma, St. Louis, MO) and $4.3 \%$ were $\mathrm{pH} 3$ to 5 (Serva Feinbiochemica GmbH \& Co., Heidelberg, Germany). The gels were prefocused at $100 \mathrm{~V}$ for 20 to $30 \mathrm{~min}$ prior to sample application. Anode buffer used was Anode fluid 3 (Bucher Instruments, Inc.,

Table 1. Origin of Stenocarpella maydis isolates examined for phenotypes

\begin{tabular}{|c|c|c|c|c|c|}
\hline $\mathbf{E T}^{\mathbf{a}}$ & Lab key $^{\text {b }}$ & Isolate numberc & Location $^{d}$ & Source & Year \\
\hline I & CB10 & 3869 & $\mathrm{AL}$ & M. Miles, Ciba Seeds & 1984 \\
\hline I & $90-135-8$ & $90-135$ & IL & J. G. Kinsey, Dekalb Plant Genetics & 1990 \\
\hline I & $87-109-1$ & $87-109$ & IL & J. G. Kinsey, Dekalb Plant Genetics & 1987 \\
\hline II & $74-189$ & 74-189 & IL & J. G. Kinsey, Dekalb Plant Genetics & 1974 \\
\hline I & $74-206$ & $74-206$ & IL & J. G. Kinsey, Dekalb Plant Genetics & 1974 \\
\hline III & CB6 & 5318 & IL & M. Miles, Ciba Seeds & $\ldots$ \\
\hline II & CB12 & 6725 & IL & M. Miles, Ciba Seeds & 1992 \\
\hline I & CB13 & 6844 & IL & M. Miles, Ciba Seeds & 1993 \\
\hline I & CB18 & 6698 & IL & M. Miles, Ciba Seeds & 1992 \\
\hline I & CB19 & 6846 & IL & M. Miles, Ciba Seeds & 1993 \\
\hline I & CB21 & 5629 & IL & M. Miles, Ciba Seeds & 1992 \\
\hline I & $\mathrm{J} 408$ & $\mathrm{~J} 400$ & IN & H. L. Warren, VPI \& SU & 1982 \\
\hline I & $93-148-3$ & $93-148$ & IN & J. G. Kinsey, Dekalb Plant Genetics & 1993 \\
\hline I & $74-193$ & $74-193$ & IN & J. G. Kinsey, Dekalb Plant Genetics & 1974 \\
\hline I & CB1 & 6773 & IN & M. Miles, Ciba Seeds & 1992 \\
\hline I & CB15 & 4552 & IN & M. Miles, Ciba Seeds & 1986 \\
\hline I & $74-191$ & $74-191$ & IA & J. G. Kinsey, Dekalb Plant Genetics & 1974 \\
\hline I & A102 & A100 & KY & P. Vincelli, Univ. of Kentucky & 1992 \\
\hline I & KY94-1 & KY94-1 & KY & P. Vincelli, Univ. of Kentucky & 1994 \\
\hline I & $74-181-2$ & $74-181$ & KY & J. G. Kinsey, Dekalb Plant Genetics & 1974 \\
\hline I & $\mathrm{CB} 2$ & 5108 & KY & M. Miles, Ciba Seeds & 1987 \\
\hline I & $74-194-1$ & $74-194$ & $\mathrm{MN}$ & J. G. Kinsey, Dekalb Plant Genetics & 1974 \\
\hline I & $87-145$ & $87-145$ & MO & J. G. Kinsey, Dekalb Plant Genetics & 1987 \\
\hline I & $87-124$ & $87-124$ & MO & J. G. Kinsey, Dekalb Plant Genetics & 1987 \\
\hline I & $85-91$ & $85-91$ & MO & J. G. Kinsey, Dekalb Plant Genetics & 1985 \\
\hline I & $86-137$ & $86-137$ & MO & J. G. Kinsey, Dekalb Plant Genetics & 1986 \\
\hline I & CB20 & 4796 & MO & M. Miles, Ciba Seeds & 1986 \\
\hline I & $91-1-1$ & $91-1$ & $\mathrm{OH}$ & J. G. Kinsey, Dekalb Plant Genetics & 1991 \\
\hline I & $87-153$ & $87-153$ & $\mathrm{OH}$ & J. G. Kinsey, Dekalb Plant Genetics & 1987 \\
\hline I & $81-87-1$ & $81-87$ & PA & J. G. Kinsey, Dekalb Plant Genetics & 1981 \\
\hline I & $85-2601$ & $85-2601$ & PA & J. G. Kinsey, Dekalb Plant Genetics & 1985 \\
\hline I & CB8 & 3419 & PA & M. Miles, Ciba Seeds & 1986 \\
\hline I & CB9 & 4554 & PA & M. Miles, Ciba Seeds & 1986 \\
\hline I & M111 & M100 & $\mathrm{TN}$ & H. L. Warren, VPI \& SU & 1985 \\
\hline I & $84-84$ & $84-84$ & $\mathrm{TN}$ & J. G. Kinsey, Dekalb Plant Genetics & 1984 \\
\hline I & $86-3326$ & $86-3326$ & $\mathrm{TN}$ & J. G. Kinsey, Dekalb Plant Genetics & 1986 \\
\hline I & CB3/CB16 & 5439 & $\mathrm{TN}$ & M. Miles, Ciba Seeds & 1989 \\
\hline I & A205 & A200 & VA & VPI \&SU Plant Disease Clinic & 1992 \\
\hline I & $\mathrm{J} 211$ & $\mathrm{~J} 200$ & VA & H. L. Warren, VPI \& SU & 1991 \\
\hline I & $\mathrm{J} 312$ & $\mathrm{~J} 300$ & VA & H. L. Warren, VPI \& SU & 1991 \\
\hline I & $\mathrm{J} 602$ & $\mathrm{~J} 600$ & VA & VPI \& SU Plant Disease Clinic & 1992 \\
\hline I & CB 7 & 6845 & $\ldots$ & M. Miles, Ciba Seeds & 1973 \\
\hline III & Ced-4 & $\ldots$ & Cedaro & B. C. Flett, Grain Crop Inst., Rep. South Africa & 1993 \\
\hline I & $\mathrm{SA}-2$ & $\ldots$ & Viljoenskroon & B. C. Flett, Grain Crop Inst., Rep. South Africa & 1993 \\
\hline IV & $\mathrm{SA}-4$ & $\ldots$ & Ermelo & B. C. Flett, Grain Crop Inst., Rep. South Africa & 1993 \\
\hline I & SA-5 & $\ldots$ & Winterton & B. C. Flett, Grain Crop Inst., Rep. South Africa & 1991 \\
\hline
\end{tabular}

\footnotetext{
${ }^{a}$ Electrophoretic type.
}

${ }^{b}$ Numbers used in collection of A. E. Dorrance.

${ }^{c}$ Numbers used by original collector.

${ }^{\mathrm{d}}$ Abbreviations for states in the United States or regions in Republic of South Africa; $\ldots=$ no information available. 
Saddlebrook, NJ), and the cathode buffer was $0.1 \mathrm{M} \mathrm{NaOH}$. The samples $(9 \mu \mathrm{l})$ were focused at a constant power of $15 \mathrm{~W}$ for 40 to $45 \mathrm{~min}$ on a flatbed electrophoresis unit (Hoefer Scientific Instruments, San Francisco, CA). Marker proteins were from Serva Test Mix 9 (Serva Feinbiochemica $\mathrm{GmbH} \&$ Co.). Pectate lyase isozymes were detected following the methods of Reid and Collmer (36). Ultrathin overlays were cast on agarose gel support film (FMC, Rockland, ME). The PGA agarose overlays contained $0.5 \%$ acid washed PGA, $50 \mathrm{mM}$ EDTA, $0.1 \mathrm{M}$ potassium acetate, $\mathrm{pH} 5.5$, and $1 \%$ agarose. Following electrophoresis, overlays were incubated at $28^{\circ} \mathrm{C}$ for 2 to $3 \mathrm{~h}$. Isozymes were detected by staining agarose overlays for 20 min with $0.05 \%$ ruthenium red. Overlays were preserved by air-drying.

Data analysis. In this study the bands were scored 1 (same location) or 0 (absent). Simple matching coefficients (SMC) were calculated as described by Groth et al. (14). Isolates were placed into four groups based on their zymograms for the enzymes assayed. Representative isolates were then analyzed with the following formula: $\mathrm{SMC}=a / n$, where $a=$ number of pairs of isozyme bands common to a pair of isolates and $n=$ total number of bands.

Pycnidiospore production. Thirty-two isolates were analyzed for pycnidiospore production in eight separate experiments. A 5-mm-diameter plug of mycelium from a 5- to 6-day-old culture of $S$. maydis was placed at the center of an APDA plate with 12 autoclaved maize kernels. Three replicate plates were made for each isolate, and plates were placed in an incubator $24 \mathrm{~cm}$ from the light source under 24-h light (24W GE Soft Light, General Electric) at $25^{\circ} \mathrm{C}$. After 3 weeks, colonized kernels from one plate were placed in a blender with $100 \mathrm{ml}$ water and ground for $60 \mathrm{~s}$ to dislodge pycnidiospores. The suspension was filtered through four layers of cheesecloth, and the filtrate volume was brought to 200 or $400 \mathrm{ml}$, depending on spore concentration. Two pycnidiospore counts were made with a hemacytometer from each flask to determine the total number of spores per plate. Each pycnidiospore experiment included standard isolate strain J211. An ANOVA was conducted on the spore counts for the standard strain from each test for significance $(P \leq 0.05)$ using the general linear model (GLM) procedure of SAS (SAS Institute, Cary, NC).

Mycelium color. Pycnidiospores of 41 $S$. maydis isolates were streaked onto separate APDA plates and placed in an incubator at $25^{\circ} \mathrm{C}$ for 12 days. A color guide was used to determine colors (21). This study was conducted three times, with each isolate compared one to three times. A second study with 17 isolates was conducted in two growth chambers to compare light effects on mycelial color development at $25^{\circ} \mathrm{C}$. Lighting in one growth chamber was from four fluorescent bulbs (15 amp F96T12/CWX/HO), the second growth chamber had a bank of 10 fluorescent bulbs (F48T12/CW/VHO, Philips Lighting, Bloomhead, NJ) and 12 incandescent bulbs (25W, General Electric) for balanced illumination.

Optimum growth temperature. Plugs of mycelia (5 $\mathrm{mm}$ diameter) were taken from 5- to 7-day-old cultures of S. maydis and placed at the edge of an APDA plate. Plates were placed in incubators under 24h light (GE 24W, cool white, General Electric) at $18,23,28$, and $33^{\circ} \mathrm{C}$. Three replicates for each isolate and temperature were made. Measurements were taken daily for 4 days from the edge of the plug to the edge of the colony. Optimum temperature was determined from plots of growth versus number of days.

\section{RESULTS}

Isozymes. A total of 23 intracellular enzymes were assayed for staining activity, of which 13 showed reliable activity to be scored; however, due to missing data, only the results from 10 enzymes are reported here. Few isozyme polymorphisms were detected among the $46 \mathrm{~S}$. maydis isolates analyzed. The U.S. and South African isolates were monomorphic or produced the same isozyme pattern for seven of the 10 enzymes (Figs. 1 and 2). Polymorphisms

Table 2. Enzymes examined for polymorphisms in a collection of Stenocarpella maydis isolates from the United States and the Republic of South Africa

\begin{tabular}{lccc}
\hline Enzyme & Abbreviation & EC No. & Reference \\
\hline Aspartate aminotransferase & AAT & 2.6 .1 .1 & 42 \\
$\alpha$-Esterase & EST & 3.1 .1 .2 & 4 \\
$\beta$-Glucosidase & GLU & 3.2 .1 .21 & 42 \\
Glutamate dehydrogenase & GDH & 1.4 .1 .4 & 28 \\
Hexokinase & HEX & 2.7 .1 .1 & 42 \\
Malate dehydrogenase & MDH & 1.1 .1 .37 & 42 \\
Phosphoglucomutase & PGM & 5.4 .2 .5 & 28 \\
Superoxide dismutase & SOD & 1.15 .1 .1 & 42 \\
Xanthine dehydrogenase & XDH & 1.1 .1 .204 & 39 \\
Pectate lyase & PL & 4.2 .2 .2 & 35 \\
\hline
\end{tabular}

a International Union of Biochemistry (1984) Enzyme Nomenclature, Academic Press, New York.

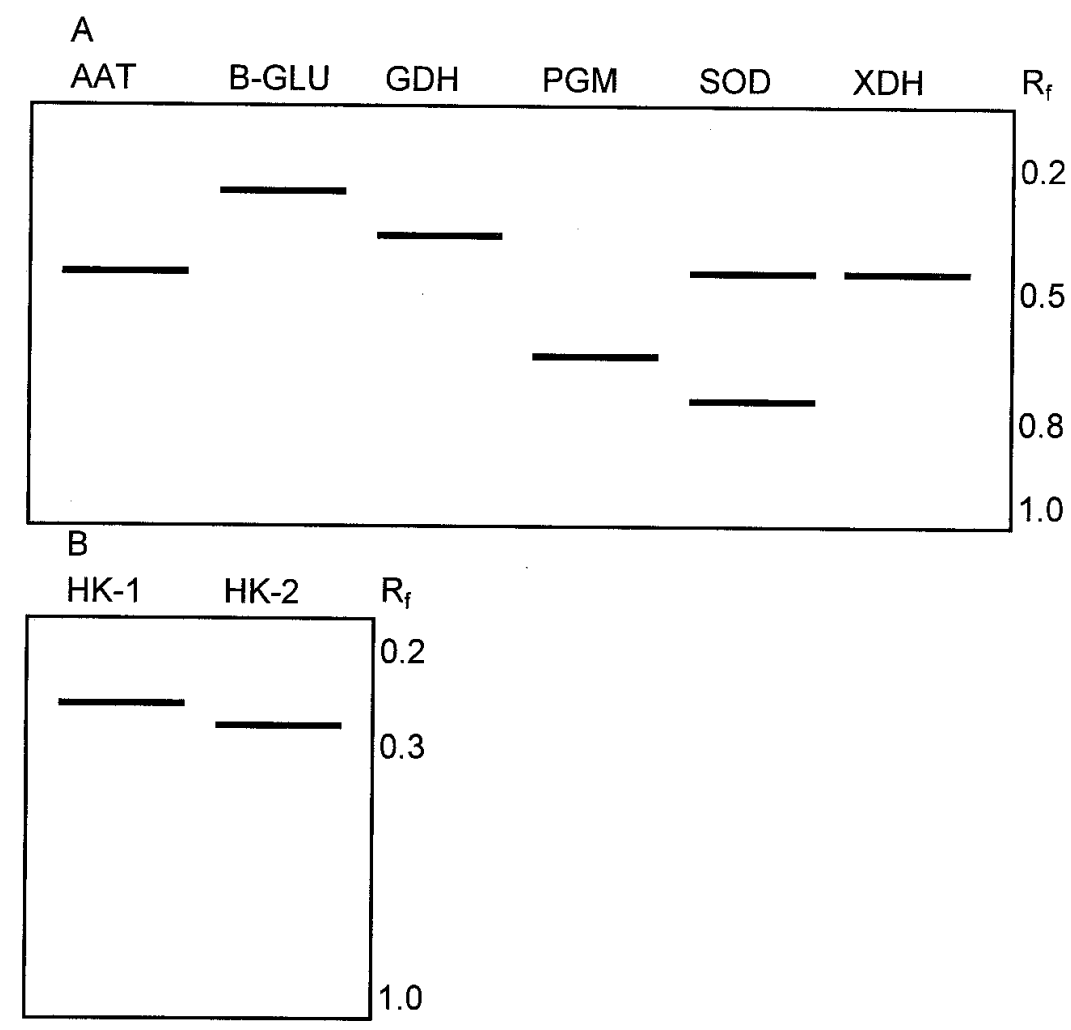

Fig. 1. Isozyme banding patterns from intracellular protein extracts of Stenocarpella maydis determined on $7.5 \%$ vertical polyacrylamide gels. Protein extracts are from mycelium from 5- to 7-dayold cultures grown on liquid potato dextrose broth. (A) All 46 isolates had the same banding pattern for: $\mathrm{AAT}=$ aminoaspartate transferase, $\beta$-GLU $=\beta$-glucosidase, $\mathrm{GDH}=$ glutamate dehydrogenase, $\mathrm{PGM}=$ phosphoglucomutase, $\mathrm{SOD}=$ superoxide dismutase, and $\mathrm{XDH}=$ xanthine dehydrogenase . (B) $\mathrm{HK}=$ hexose kinase, where HK-1 bands were recorded for 43 out of 46 isolates and HK-2 was recorded for three isolates. $R_{f}$ is mobility relative to enzyme front. 
were detected in the U.S. population for $\alpha$ esterase, malate dehydrogenase, and hexose kinase, while the South African populations were polymorphic for hexose kinase and malate dehydrogenase (Figs. 1 and 2). A single allele was detected in the enzyme systems, aminoaspartate trans-

A B

EST-1 EST-2 $R_{f} \quad M D H-1 M D H-2 R_{f}$

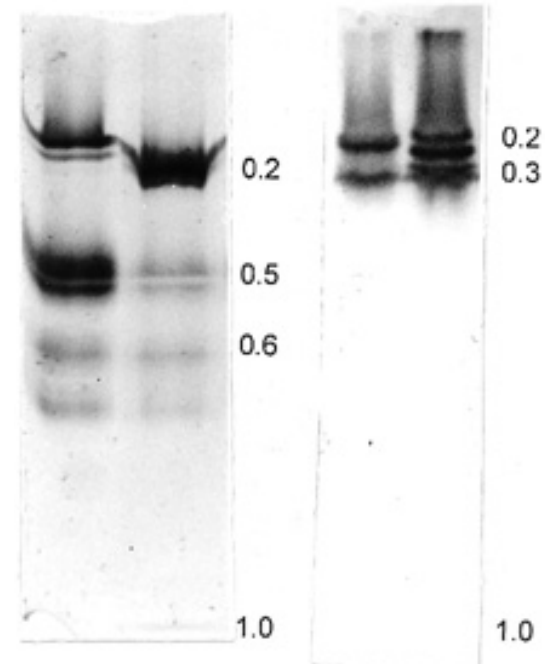

C

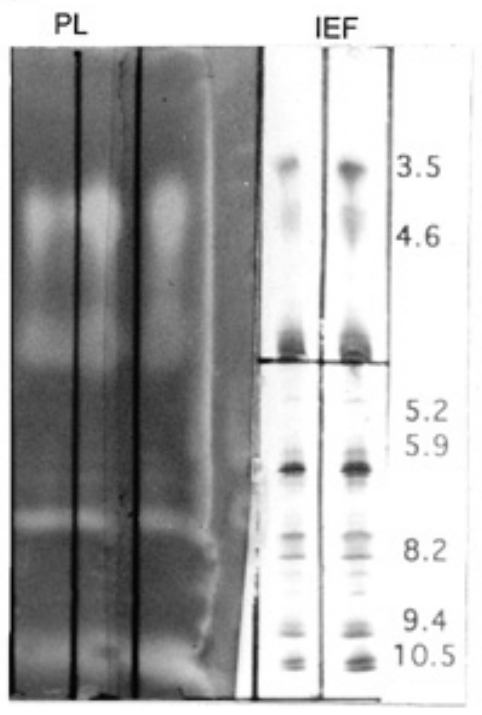

Fig. 2. Isozyme banding patterns from Stenocarpella maydis. (A) EST = esterase, determined from intracellular protein extracts on $7.5 \%$ vertical polyacrylamide gels. EST-1 bands were recorded from 44 out of 46 isolates and EST-2 from two isolates. (B) $\mathrm{MDH}=$ malate dehydrogenase, determined on $10.0 \%$ acrylamide. MDH-1 bands were recorded for 45 out of 46 isolates, and MDH-2 was recorded for one isolate. (C) $\mathrm{PL}=$ pectate lyase, bands determined on agarose overlays ( $\mathrm{pH}$ 5.5) from an isoelectric focusing gel. Proteins were concentrated from extracellular culture fluid where polygalacturonic acid served as the carbon source. $R_{f}$ is the mobility relative to enzyme front, and PI markers are Protein Test Mix 9, Serva, Feinbiochemica. ferase (AAT), $\beta$-glucosidase ( $\beta$-GLU), glutamate dehydrogenase (GDH), hexose kinase (HEX), phosphoglucomutase (PGM), and xanthine dehydrogenase (XDH). Multiple bands were produced by $\alpha$-esterase (EST), malate dehydrogenase (MDH), superoxide dismutase (SOD), and pectate lyase (PL). A total of 28 putative loci were identified in this group of isolates with these enzymes. Isozymes that formed faint bands or those that were inconsistent between analyses were not counted (46). The one isolate of $D$. nataliensis that was analyzed had the same banding pattern as $S$. maydis for only two enzymes, glutamate dehydrogenase and phosphoglucomutase; no bands were present under these staining conditions for HK; single bands were resolved for AAT, $\beta$-GLU, XDH; and four bands for $\alpha$-EST. $S$. maydis isolates were placed into four electrophoretic types (Table 1) based on their zymograms for the enzymes assayed. Even with the few differences reported, SMC values ranged from 0.71 to 0.92 (Table 3).

Pycnidiospore production. There were significant differences $(P=0.043)$ among tests for numbers of spores per plate of the standard isolate $S$. maydis strain J211. Pycnidiospore production ranged from $4.63 \times 10^{7}$ to $1.37 \times 10^{8}$ pycnidiospores per plate. There was considerable variation among isolates within tests. In some cases, a plate would have no pycnidia, while another plate of the same isolate developed numerous pycnidia in the same experiment; thus, plates that did not produce pycnidia were not included in the final means. Fungi Imperfecti, such as S. maydis, can lose the ability to produce conidia after repeated fungal transfers (38).

Mycelial color. The color of the mycetests, and the results were highly variable. For example, strain 85-2601 was white to grayish red (p7B5) in test 2 , but the results in test 3 were white to orange-gray (p5B2). For a majority of the isolates, the color of $S$. maydis mycelium was white with black pycnidia surrounded by areas of brownish orange (p7C4) or Sahara (6C5). Other mycelium color phenotypes recorded were: white to reddish gray (p7B2), grayish brown (6D3), brownish orange (p6C4), brownish red (8C4), and pinkish white lium changed for specific isolates between

(p7A2). When pycnidiospores were transferred to two plates and placed under two different light systems, there was some phenotype difference in nine out of 18 strains. It is unlikely that this would have been a mutation due to the number of pycnidiospores transferred. The same color phenotype could not be reproduced in successive runs of the experiment in the same incubator. The color ranges were white with numerous black pycnidia to white with areas of Sahara (p.5A2) to mostly grayish red.

Optimum temperature. Growth curves were generated from the measurements of mycelial growth over time. The optimum temperature was estimated from these curves, and the majority of isolates fell within the range 29 to $32 \pm 2^{\circ} \mathrm{C}$. One isolate, SA4-1, had an optimum of $27^{\circ} \mathrm{C}$ in one test, but when retested it was $29 \pm 2^{\circ} \mathrm{C}$. The standard isolate, J211, was fairly consistent in its optimum temperature, 30 to $31^{\circ} \mathrm{C}$, but in one assay its optimum was $32^{\circ} \mathrm{C}$.

\section{DISCUSSION}

Our collection of $S$. maydis isolates from the United States and the Republic of South Africa showed little isozyme variation for the 10 enzymes assayed. We expected to detect isozyme variation based on previous reports of variability for aggressiveness and pycnidiospore production of this fungus $(6,19,26,41,45)$. However, this fungus has only two reported hosts, maize and Arundinaria (37). Several researchers have reported similar results with fungi that have host specialization, as a formae speciales or biotrophic obligate parasite. Pathogenic fungi with limited variation in isozyme patterns among formae speciales or obligate parasites include: Ustilago hordei (15), Erysiphe graminis f. sp. hordei (7), Phytophthora megasperma (34), Fusarium oxysporum (3), and Puccinia striiformis (33). Wheat and barley isolates of Pseudocercosporella herpotrichoides could be separated by isozyme analysis (18). In contrast, a great deal of isozyme variation for specific enzymes among isolates of necrotrophic plant pathogenic fungi has been reported, including Rhynchosporium secalis $(13,32)$ and Alternaria solani and A. alternata (35). There are

Table 3. Simple matching coefficients (SMC) for 46 isolates of Stenocarpella maydis using $10 \mathrm{en}$ zymes

\begin{tabular}{lcccc}
\hline Group & I $^{\mathbf{a}}$ & II & III & IV \\
\hline I & $\ldots$ & $24 / 26^{\mathrm{b}}$ & $22 / 26$ & $22 / 24$ \\
II & $0.92^{\mathrm{c}}$ & $\ldots$ & $20 / 28$ & $20 / 26$ \\
III & 0.84 & 0.71 & $\ldots$ & $22 / 24$ \\
IV & 0.92 & 0.77 & 0.92 & $\ldots$ \\
\hline
\end{tabular}

${ }^{a}$ Isozyme banding groups: $\mathrm{I}=$ most common isozyme group (41 isolates), $\mathrm{II}=\alpha$-esterase - two isolates, III $=$ hexokinase and malate dehydrogenase - two isolates, and IV $=$ hexose kinase - one isolate.

${ }^{b}$ Ratio of number of common pairs of isozyme bands to total isozyme bands detected in this set of isolates (14).

${ }^{\mathrm{c}}$ Simple matching coefficients. 
exceptions, in that Elias and Schneider (10) reported that eight of 30 isozyme loci were variable among isolates of $F$. oxysporum $\mathrm{f}$. sp. lycopersici, but that the electrophoretic types still remained tightly clustered based on SMC coefficients. In addition, Groth et al. (14) reported isozyme variation in both sexual and asexually reproducing populations of the bean rust fungus, Uromyces appendiculatus.

Several hypotheses have been proposed for the lack of isozyme polymorphisms found in formae speciales and biotrophs. Hellmann and Christ (15) proposed inbreeding, common origin, and lack of necessity for enzyme variation as possible explanations for the few electrophoretic types in $U$. hordei. It has been proposed that founder effects may be responsible for the uniformity of isozymes detected among isolates of $P$. graminis f. sp. tritici and $P$. recondita f. sp. tritici (5) and Magnaporthe grisea (24). Hellmann and Christ (15) also proposed that the isozymes may be subject to different selection pressures. The selection pressure on these enzymes may be so small that there is little advantage to be gained by enzyme variation.

In contrast, others have suggested the selection pressure placed on the pathogen by the specific host is great, which results in minimal enzyme variability. Elias and Schneider (10) concluded that the host plant exerts the primary selection pressure on $F$. oxysporum f. sp. lycopersici, which does not have a significant saprophytic phase in its life cycle. Kurzeja and Garber (22) reported little variation in amylase patterns for the haploid fungus, Aspergillus nidulans. They hypothesized that this is a result of immediate selection pressure placed on new mutations. Clark et al. (7) suggested that barley as a host may impose particularly stringent biochemical requirements on mildew and exert strong selection against any variation. Newton et al. (33) hypothesized that highly specialized obligate parasites with no sexual reproduction are likely to be under higher selection pressure and to exhibit less variation than necrotrophic fungi such as $R$. secalis. They hypothesized that obligate parasites seem to exhibit lower levels of isozyme variability because they encounter a more uniform substrate and environment than do facultative parasites, which often have broader host range and colonize different substrates in different environments.

Genetic bottlenecks may also account for the lack of variation among the isolates of $S$. maydis examined in this study. Historically, Diplodia ear rot and stalk rot were the important diseases of maize in the early part of this century, but they became scarce during the 1960s and early 1970 s (16). This decline in incidence was thought to be the result of extensive use of resistant hybrids, which would result in a decline in populations of $S$. maydis. Genetic bottlenecks are thought to account for some of the lack of variation in Phytophthora infestans clonal populations in Europe and North America following the first introductions in the 1840s (12).

From our study, we cannot determine if the relative lack of isozyme polymorphism in $S$. maydis is due to a lack of selection pressure, the result of a stringent biochemical requirement placed on the fungus by the host or genetic bottlenecks. It is significant that S. maydis is similar to other fungi that have uniform isozyme polymorphisms and are host specific $(3,7,15,18,34)$. This may be due to the haploid state of these fungi, so that following a mutation, there would be immediate selection pressure placed on the fungus. A sexual stage has not been reported for $S$. maydis; therefore sexual recombination is not known. Due to previous reports of variability among isolates of $S$. maydis, the wide geographic regions from which the isolates were collected, and the array of enzymes analyzed, we expected to find more variation. There does exist the possibility that these results are biased due to the enzymes that were tested, but many of these have shown variability with other pathogens. Further isozyme analysis that incorporates more enzymes and a larger collection of isolates from other geographic regions may eventually reveal some level of variability. More importantly, more robust techniques to examine variation at the DNA level may reveal a greater genetic diversity that was not detected by the isozyme analysis. In addition, an expanded study of isolates from the Republic of South Africa, where Stenocarpella populations have not declined, would be a possible means to test the influence of genetic bottlenecks on population variability. Further genetic analysis is needed to determine if the $S$. maydis population is uniform and behaves in a similar manner to other fungi that have host specificity or are biotrophs.

The cultural characteristics among $S$. maydis isolates proved to be quite variable and unstable. There was a significant difference in the production of pycnidiospores by the standard isolate, and the color phenotype was also quite variable. Both of these traits are influenced by genetic and environmental cues. These two traits are not good features on which to base a study of genetic variability. This confirms previous reports that there is variability for pycnidiospore production; however, these studies also suggest that it is not a stable phenotype.

\section{ACKNOWLEDGMENTS}

We thank Paul Vincelli and Steven Goodwin for providing comments and suggestions for this manuscript, and Alice Way and Verlyn Stromberg for technical support. A portion of this research was supported by a grant from the Graduate Research Development Program at Virginia Polytechnic Institute and State University in 1994.

\section{LITERATURE CITED}

1. BeMiller, J. N., Tegtmeier, D. O., and Pappelis, A. J. 1969. Effect of phenolics and indole3-acetic acid on production and activity of cellulolytic and pectolytic enzymes of Diplodia zeae. Phytopathology 59:1336-1339.

2. Bonde, M. R., Micales, J. A., and Peterson, G. L. 1993. The use of isozyme analysis for identification of plant-pathogenic fungi. Plant Dis. 77:961-968.

3. Bosland, P. W., and Williams, P. H. 1987. An evaluation of Fusarium oxysporum from crucifers based on pathogenicity, isozyme polymorphism, vegetative compatibility, and geographic origin. Can. J. Bot. 65:2067-2073.

4. Brewbaker, J. L., Upadhya, M. D., Makinen, Y., and MacDonald, T. 1968. Isoenzyme polymorphism in flowering plants III. Gel electrophoresis methods and applications. Physiol. Plant. 21:930-940.

5. Burdon, J. J., Luig, N. H., and Marshall, D. R. 1983. Isozyme uniformity and virulence variation in Puccinia graminis f. sp. tritici and $P$. recondita $\mathrm{f}$. $\mathrm{sp}$. tritici in Australia. Aust. J. Biol. Sci. 36:403-410.

6. Chambers, K. R. 1988. Effect of time of inoculation on Diplodia stalk and ear rot of maize in South Africa. Plant Dis. 72:529-531.

7. Clark, J., Butters, J., Brent, K. J., and Hollomon, D. W. 1989. Isozyme uniformity in Erysiphe graminis f. sp. hordei. Mycol. Res. 92:404-409.

8. Dorrance, A. E., Stromberg, V. K., Warren, H. L., and Lacy, G. H. 1994. Pectic isoenzymes of Stenocarpella maydis (Diplodia maydis). (Abstr.) Phytopathology 84:1108.

9. Dorrance, A. E., Way, A. W., Lacy, G. H., and Warren, H. L. 1995. Isoenzymes of Stenocarpella maydis. (Abstr.) Phytopathology 85:630.

10. Elias, K. S., and Schneider, R. W. 1992. Genetic diversity within and among races and vegetative compatibility groups of Fusarium oxysporum f. sp. lycopersici as determined by isozyme analysis. Phytopathology 82:14211427.

11. Flett, B. C., and McLaren, N. W. 1994. Optimum disease potential for evaluating resistance to Stenocarpella maydis ear rot in corn hybrids. Plant Dis. 78:587-589.

12. Goodwin, S. B. 1997. The population genetics of Phytophthora. Phytopathology 87:462473.

13. Goodwin, S. B., Saghai Maroof, M. A., Allard, R. W., and Webster, R. K. 1993. Isozyme variation within and among populations of Rhynchosporium secalis in Europe, Australia and the United States. Mycol. Res. 97:49-58.

14. Groth, J. V., McCain, J. W., and Roelfs, A. P. 1995. Virulence and isozyme diversity of sexual versus asexual collections of Uromyces appendiculatus (bean rust fungus). Heredity 75:234-242.

15. Hellmann, R., and Christ, B. J. 1991. Isozyme variation of physiologic races of Ustilago hordei. Phytopathology 81:1536-1540.

16. Hooker, A. L., and White, D. G. 1976. Prevalence of corn stalk rot fungi in Illinois. Plant Dis. Rep. 60:1032-1034.

17. Hoppe, P. E. 1936. Intraspecific and interspecific aversion in Diplodia. J. Agric. Res. 53:671-680.

18. Julian, A. M., and Lucas, J. A. 1990. Isozyme polymorphism in pathotypes of Pseudocercosporella herpotrichoides and related species from cereals. Plant Pathol. 39:178-190.

19. Kappelman, A. J., Thompson, D. L., and Nelson, R. R. 1965. Virulence of 20 isolates of Diplodia zeae as revealed by stalk rot development in corn. Crop Sci. 5:541-543.

20. Kohn, L. M. 1992. Developing new characters for fungal systematics: An experimental approach for determining the rank of resolution. Mycologia 84:139-153. 
21. Kornerup, A., and Wanscher, J. W. 1961. Methuen Handbook of Colour. Metheun Co., London.

22. Kurzeja, K. C., and Garber, E. D. 1973. A genetic study of electrophoretically variant extracellular amylolytic enzymes of wild-type strains of Aspergillus nidulans. Can. J. Genet. Cytol. 15:275-287.

23. Latterell, F. M., and Rossi, A. E. 1983. Stenocarpella macrospora (=Diplodia macrospora) and $S$. maydis (=D. maydis) compared as pathogens of corn. Plant Dis. 67:725-729.

24. Leung, H., and Williams, P. H. 1986. Enzyme polymorphisms and genetic differentiation among geographic isolates of the rice blast fungus. Phytopathology 76:778-783.

25. Loesch, P. J., Jr., Calvert, O. H., and Zuber, M. S. 1962. Interrelations of Diplodia stalk rot and two morphological traits associated with the lodging of corn. Crop Sci. 2:469-472.

26. Maxwell, J. D., and Thompson, D. L. 1974. Mutual balance between tester resistance and isolate virulence in the evaluation of corn inbreds for Diplodia stalk rot. Crop Sci. 14:594595.

27. McDonald, B. A., and McDermott, J. M. 1993. Population genetics of plant pathogenic fungi. BioScience 43:311-319.

28. Meijer, G., Megnegneau, B., and Linders, E. G. A. 1994. Variability for isozyme, vegetative compatibility and RAPD markers in natural populations of Phomopsis subordinaria. Mycol. Res. 98:267-276.

29. Micales, J. A., Bonde, M. R., and Peterson, G. L. 1986. The use of isozyme analysis in fun- gal taxonomy and genetics. Mycotaxon 27:405-449.

30. Morant, M. A., Warren, H. L., and von Qualen, S. K. 1993. A synthetic medium for mass production of pycnidiospores of Stenocarpella species. Plant Dis. 77:424-426.

31. Munkvold, G. P., and Yang, X. B. 1995. Crop damage and epidemics associated with 1993 floods in Iowa. Plant Dis. 79:95-101.

32. Newman, P. L. 1985. Variation amongst isozymes of Rhynchosporium secalis. Plant Pathol. 34:329-337.

33. Newton, A. C., Caten, C. E., and Johnson, R. 1985. Variation for isozymes and doublestranded RNA among isolates of Puccinia striiformis and two other cereal rusts. Plant Pathol. 34:235-247.

34. Nygaard, S. L., Elliott, C. K., Cannon, S. J., and Maxwell, D. P. 1989. Isozyme variability among isolates of Phytophthora megasperma. Phytopathology 79:773-780.

35. Petrunak, D. M., and Christ, B. J. 1992 Isozyme variability in Alternaria solani and A. alternata. Phytopathology 82:1343-1347.

36. Reid, J. L., and Collmer, A. 1985. Activity stain for rapid characterization of pectic enzymes in isoelectric focusing and sodium dodecyl sulfate polyacrylamide gels. Appl. Environ. Biol. 50:615-622.

37. Sutton, B. C. 1980. The Coelomycetes Fungi Imperfecti with Pycnidia, Acervuli and Stromata. Commonw. Mycol. Inst., Kew, Eng.

38. Tuite, J. 1969. Plant Pathological Methods Fungi and Bacteria. Burgess Publishing, Minneapolis, MN.
39. Ullstrup, A. J. 1949. A method for producing artificial epidemics of Diplodia ear rot. Phytopathology 39:93-101.

40. Vallejos, C. E. 1983. Enzyme activity staining. Pages 469-516 in: Isozymes in Plant Genetics and Breeding, Part A. S. D. Tanksley and T. J. Orton, eds. Elsevier Science Publishers, Amsterdam.

41. Villena, W. L. 1969. Studies of inoculation methods and inheritance of resistance to diplodia ear rot in corn. Ph.D. diss. North Carolina State University, Raleigh.

42. Vogler, D. R., Kinloch, B. B., Jr., Cobb, F. W., Jr., and Popenuck, T. L. 1991. Isozyme structure of Peridermium harknessii in the western United States. Can. J. Bot. 69:2434-2441.

43. Wendel, J. F., and Weeden, N. F. 1989. Visualization and interpretation of plant isozymes. Pages 5-45 in: Isozymes in Plant Biology. D E. Soltis and P. S Soltis, eds. Dioscorides Press, Portland, OR.

44. Young, H. C., Jr. 1943. The toothpick method of inoculating corn for ear and stalk rots. (Abstr.) Phytopathology 33:16.

45. Young, H. C., Jr., Wilcoxson, R. D., Whitehead, M. D., DeVay, J. E., Grogan, C. O., and Zuber, M. S. 1959. An ecological study of the pathogenicity of Diplodia maydis isolates inciting stalk rot of corn. Plant Dis. Rep. 43:1124-1129.

46. Zambino, P. J., and Harrington, T. C. 1992 Correspondence of isozyme characterization with morphology in the asexual genus Leptographium and taxonomic implications. Mycologia 84:12-25. 